\title{
Lean Management w usługach, czyli jak zjeść bez kolejki
}

http://dx.doi.org/10.18778/8142-085-3.03

\author{
Jagoda Matyla, Alicja Wójcik \\ Koło Naukowe „Logistyka” \\ Wydział Inżynierii Zarządzania, Politechnika Poznańska
}

\section{Wstęp}

Coraz więcej przedsiębiorstw chce być Lean, chce wprowadzać Lean w swoich przedsiębiorstwach. Lean Management jest koncepcją „odchudzonego” funkcjonowania firmy. Polega na znacznym ograniczeniu potrzebnych do produkcji zasobów, skupia się na poszukiwaniu oraz eliminowaniu wszelkiego marnotrawstwa, osiąganiu racjonalności w obszarach działalności firmy, a także w gospodarowaniu jej zasobami. Zakłada podejście ewolucyjne: powolne i systematyczne wprowadzanie zmian (Grzyl, 2012).

Lean Management kojarzony jest głównie z przedsiębiorstwami produkcyjnymi, w których najprościej jest go wprowadzić, a efekty są najszybciej widoczne. Należy jednak pamiętać, że filozofię tę można stosować także w usługach, czyli w działalności gospodarczej służącej zaspokajaniu potrzeb ludzi i tej sfery dotyczy niniejszy referat. Pomimo innej specyfiki realizowanych procesów, innych kluczowych wskaźników czy nawet pierwotnych przyczyn problemów niż w przedsiębiorstwach produkcyjnych, metody Lean są równie skuteczne w sektorze usług ${ }^{1}$.

\section{Lean w ustugach}

Wbrew pozorom, korzyści z wprowadzenia Lean w usługach mogą być większe niż w sektorze produkcyjnym. Ma to związek z faktem, że większość firm produkcyjnych przez lata starała się zwiększać produktywność, nawet gdy o Lean jeszcze nikt nie mówił. W sektorze usług natomiast nigdy nie było presji na doskonalenie

1 http://sjp.pwn.pl/sjp/uslugi;2533507.html [dostęp 18.04.2016]. 
pracy tworzącej wartość, ponieważ odbywała się ona przy „biurkach” ludzi pracujących w różnych budynkach, na różnych piętrach. Zdecydowanie łatwiej pójść na halę i zaobserwować proces produkcyjny, niż chodzić po pokojach i szukać procesów, które można by usprawnić.

Zastosowanie Lean w przedsiębiorstwie usługowym również pomoże przyśpieszyć proces przy zachowaniu dobrej jakości. Poprzez zwiększenie tempa wykonywania usługi przedsiębiorstwo może bardziej elastycznie odpowiadać na potrzeby klienta i reagować na warunki panujące na rynku. Przyśpieszenie takie można uzyskać na dwa sposoby. Pierwszy z nich to obserwowanie procesu i eliminowanie czynności i zadań, które nie przynoszą wartości dodanej. Można również dokonać przeorganizowania procesu. Drugim sposobem jest przydzielenie uprawnień do działania pracownikom posiadającym osobisty kontakt z klientem, którzy mogą działać bez proszenia o zgodę kierownika czy przełożonego. Wpływa to na wzrost zaangażowania pracownika i chęć poświęcenia większej uwagi klientowi. Wprowadzenie szybszej reakcji, jaka dzięki temu jest osiągana, wpływa z kolei na zwiększenie zysków przedsiębiorstwa.

\section{Lean w gastronomii}

\subsection{Wykorzystanie narzędzi Lean}

Nietypową usługą, w której znaleźć mogą zastosowanie narzędzia Lean Management, jest gastronomia. Każdy z nas zetknął się z kolejką w restauracji czy kawiarni lub długim czasem oczekiwania na realizację zamówienia. Co zatem mogłyby uczynić restauracje oraz punkty gastronomiczne, aby skrócić czas od przyjęcia zamówienia do jego realizacji?

Z pomocą przychodzą narzędzia Lean. Tabela 1 przedstawia najpopularniejsze narzędzia Lean, wraz z określeniem ich przydatności w gastronomii.

Tabela 1. Przydatność narzędzi Lean w restauracji

\begin{tabular}{|c|l|c|}
\hline Lp. & \multicolumn{1}{|c|}{ Narzędzie } & Przydatność \\
\hline 1 & Poka-Yoke & tak \\
\hline 2 & Heijunka & nie \\
\hline 3 & TPM & nie \\
\hline 4 & VSM & nie \\
\hline 5 & Kanban & tak \\
\hline
\end{tabular}




\begin{tabular}{|c|l|c|}
\hline Lp. & \multicolumn{1}{|c|}{ Narzędzie } & Przydatność \\
\hline 6 & SMED & tak \\
\hline 7 & 5 S & tak \\
\hline 8 & Zarządzanie wizualne & tak \\
\hline 9 & Diagram Ishikawy & tak \\
\hline 10 & 5 why & nie \\
\hline 11 & Hoshin Kanri & nie \\
\hline 12 & Arkusz A3 & tak \\
\hline 13 & Andon & tak \\
\hline 14 & System pull/ ssący & tak \\
\hline 15 & PDCA & Zródo: \\
\hline
\end{tabular}

Źródło: opracowanie własne.

Przykład zastosowania metody Kanban możemy znaleźć w sieci restauracji McDonalds. Kanban jest sygnałem, który wywołuje uzupełnienie zasobów lub wycofanie w systemie ciągnionym. Często przyjmuje postać formularza, deponowanego w specjalnym pojemniku na hali produkcyjnej. Sygnał reguluje przepływ produkcji w strumieniu wartości (Sayer, Williams, 2015: 348). Gdy zaczyna brakować jednej z najbardziej popularnych kanapek, kasjer wystawia informację, czyli kartę Kanban, która jest sygnałem dla kuchni, by zacząć produkcję. Dzięki temu utrzymany jest balans pomiędzy nadmiernymi zapasami a długim czasem oczekiwania.

Zastosowanie metody $5 \mathrm{~S}$ widoczne jest w restauracjach, w których klient sam powinien posprzątać zajmowany przez siebie stolik i odnieść zużyte naczynia. Wówczas podchodzi on z tacą do punktu oznaczonego napisem „zwrot naczyń” lub do pojemników na odpady, które w graficzny sposób sugerują, gdzie powinny trafić dane odpady. Innym zastosowaniem metody 5S jest utrzymywanie krótkiej karty dań, dzięki czemu metodą selekcji wybierane są tylko najczęściej zamawiane dania. Przy mniejszym wyborze dań kuchnia w krótszym czasie jest w stanie zrealizować zamówienie, a także nie musi przetrzymywać rzadko stosowanych składników. Poza tym 5S może być zastosowane również w kuchni, gdzie po zweryfikowaniu i pozostawieniu tylko potrzebnych naczyń i sprzętów, każde z nich ma swoje miejsce, w którym nieużywane powinno się znajdować. Oszczędza to cenny czas kucharzy, którzy nie muszą szukać potrzebnych składników, wiec mogą szybciej wykonać swoją pracę.

Kolejnym narzędziem, jakie przyśpieszy proces, jest zarządzanie wizualne. Zarządzanie wizualne „Hala produkcyjna ma do Ciebie mówić” to system prostych narzędzi wizualizacji - wykresów, pól odkładczych, zdjęć, kolorów itp., które 
sprawiają, że bez zaglądania do komputera czy dokumentacji można określić, co dzieje się na produkcji². Dobrym pomysłem jest ułożenie naczyń i sztućców na stołach jeszcze przed przyjściem klienta. Kelner może tego dokonać dzięki tablicy informacyjnej, która powie mu, gdzie powinien na przykład stać kieliszek do białego, a gdzie do czerwonego wina, tak by nawet najbardziej wymagający klient był zadowolony.

Diagram Ishikawy oraz 5 why w przypadku restauracji to metody pomocnicze, niewpływające bezpośrednio na czas oczekiwania. Jeżeli chodzi o 5 why, jest to metoda analizy pozwalająca dotrzeć do pierwotnej przyczyny poprzez powtarzanie pytania „dlaczego?” przynajmniej pięć razy lub do momentu dotarcia do pierwotnej przyczyny (Sayer, Williams, 2015: 347). W momencie pojawienia się problemu wpływającego na czas obsługi pytania te są $\mathrm{w}$ stanie pomóc go przeanalizować i wyeliminować. Przykładem mogą być problemy dotyczące np. kwestii, dlaczego zostaje tyle składników - może dlatego, że restauracja posiada za dużą kartę.

Andon to urządzenie kontrolne, które za pomocą sygnałów świetlnych lub dźwiękowych informuje o problemach. Jest to element wyposażenia umożliwiający funkcjonowanie automatyzmu. Alarm uruchamia pracownik lub inicjuje go urządzenie. Umożliwia on praktyczne zastosowanie zasady „nie przyjmuj wady, nie produkuj wady, nie wysyłaj wady"3. W niektórych galeriach handlowych dostaje się przy złożeniu zamówienia małe urządzenie, które wibruje, gdy zamówienie jest gotowe do odbioru. Podobny wynik uzyskiwany jest w McDonald's, gdzie na monitorze wyświetla się numery zamówień wszystkich klientów, a gotowe zamówienia są powiększone oraz umieszczone po prawej stronie monitora.

W systemie pull produkcja ciągniona jest od zamówienia klienta. Kupiony produkt to sygnał, że towar wyszedł z magazynu i musi być zastąpiony przez nowy, wyprodukowany. Przy pomocy kart Kanban podobna informacja przechodzi od stanowiska do stanowiska - przez całą produkcję. Pull system likwiduje czas oczekiwania, zapasy i nadprodukcję. Jest jedną z trzech podstaw JIT ${ }^{4}$. Przykładem systemu pull w usługach mogą być pulpity w McDonalds, gdzie klient składa zamówienie nie musząc stać w kolejce.

\subsection{Lean restaurant metodą na zwiększenie zadowolenia klientów}

Pierwszą rzeczą, jaką się różni restauracja Lean od tradycyjnej restauracji, jest brak menu, a raczej nie ma menu w tradycyjnym rozumieniu. W Lean restaurant przy każdym stoliku zamontowany jest tablet z przyjaznym dla klienta

2 http://leanmanufacturing.pl/slownik/v/visual-management.html [dostęp 18.04.2016].

3 http://leanmanufacturing.pl/slownik/a/andon.html [dostęp 18.04.2016].

4 http://leanmanufacturing.pl/slownik/p/pull-system.html [dostęp 18.04.2016]. 
prostym oprogramowaniem zawierającym menu. W prosty sposób klient może złożyć zamówienie, zapłacić, poprosić obsługę o podejście czy o przyniesienie dodatkowej zastawy. Biorąc pod uwagę formy płatności, klient ma do wyboru bardzo szeroką gamę. Można wyróżnić PayU, PayPal czy PayByNet, a także zwykły przelew czy płatność gotówką u kelnera. Po wyborze odpowiednich pozycji z menu i formy płatności, pozostaje klientowi zatwierdzenie zamówienia i oczekiwanie na danie. $W$ tym procesie rola kelnera jest bardzo uproszczona. Musi on zadbać jedynie o przyniesienie potrawy z kuchni i sprawdzenie, czy goście są zadowoleni.

Podczas wizyty w Lean restaurant skrócony jest lead time. Klienci nie oczekują na podejście kelnera, by móc złożyć zamówienie, domówić jakąś pozycję czy zapłacić w wybranym przez siebie momencie. Konsekwencją skrócenia lead time jest możliwość obsłużenia większej liczby gości. Rotacja stolików jest także większa. Taka sytuacja generuje większą sprzedaż, a co za tym idzie - większy zysk. Klienci ceniący czas są zadowoleni, ponieważ nie tracą go czekając na kelnera czy na wykonanie czynności związanych z płatnościami lub zamówieniami.

Nie tylko goście odczuwają zalety tego rozwiązania, ale także właściciel restauracji. Przy wprowadzeniu zaproponowanego systemu zmniejsza się liczba potrzebnych pracowników. Generuje to spadek kosztów ponoszonych przez właściciela na wynagrodzenia pracowników.

Dzięki systemowi tabletowemu właściciel czy manager restauracji otrzymują szczegółowe raporty dotyczące np. zysku z danego stolika, czasu pobytu klientów, najczęściej zamawianych dań czy oceny pobytu w restauracji.

Zamówienia klientów kolejkowane są w systemie według FIFO, po czym przesyłane do kuchni. Kolejki FIFO dyktują kolejność wydawania zamówień. Dzięki takiemu rozwiązaniu klienci są usatysfakcjonowani, ponieważ potrawy dostarczone są ciepłe i w odpowiednim czasie.

\section{Podsumowanie}

Eksperci od wdrażania Lean w przedsiębiorstwach, skupieni głównie na produkcji, niejednokrotnie mają problem $\mathrm{z}$ narzucaniem koncepcji i języka, do którego przywykli w codziennej pracy. Jak się okazuje, jest to jedno z największych wyzwań dla ludzi, którzy wywodzą się z produkcji, a zaczynają wdrażać Lean Management w usługach. Dobra wiadomość jest jednak taka, że środowisko usługowe potrzebuje, a wręcz domaga się zarządzania opartego na zasadach Lean Management. Brak standaryzacji czy duży stopień zmienności w procesach usługowych 
to kwestie, w których Lean może pomóc rozwiązać wiele problemów ${ }^{5}$. Pokazane narzędzia Lean pomagają w udoskonaleniu procesów w gastronomii i osiągnięciu wyższych zysków. Należy jednak pamiętać, że narzędzi tych nie można wdrożyć w każdej restauracji. Ekskluzywne restauracje wymagają obecności kelnerów, posiadania własnego menu czy też przyniesienia zamówionego dania do stolika przez kelnera. Dlatego należy zastanowić się, jakiego typu jest dana restauracja oraz jakie narzędzia Lean sprawdzą się w niej najlepiej.

\section{Bibliografia}

Grzyl B., (2012), Logistyka w przedsiębiorstwie w świetle współczesnych koncepcji i metod zarzqdzania, „Logistyka”, nr 3, http://www.czasopismologistyka.pl/artykuly-naukowe/send/239-artykuly-na-plycie-cd/2571-artykul [dostęp 20.04.2016].

Lean Enterprise Institute Polska, Sposób Drew Lochera na wdrożenie Lean w środowisku usługowym, http://lean.org.pl/sposob-drew-lochera-wdrozenie-lean-srodowisku-uslugowym [dostęp 28.04.2016].

Sayer N., Williams B., (2015), Lean dla bystrzaków, wyd. 2, Helion, Gliwice.

Stownik Języka Polskiego, (2014), hasło „Usługi”, http://sjp.pwn.pl/sjp/uslugi;2533507.html [dostęp 18.04.2016].

Stownik pojęć zwiqzzanych z metodologiq Lean, hasło „Andon”, http://leanmanufacturing.pl/ slownik/a/andon.html [dostęp 18.04.2016].

Słownik pojęć zwiq̨zanych z metodologiq Lean, hasło „Pull system”, http://leanmanufacturing.pl/ slownik/p/pull-system.html [dostęp 18.04.2016].

Stownik pojęć zwiq̨zanych z metodologiq Lean, hasło „Visual management”, http://leanmanufacturing.pl/slownik/v/visual-management.html [dostęp 18.04.2016].

5 Lean Enterprise Institute Polska, Sposób Drew Lochera na wdrożenie Lean w środowisku usługowym, http://lean.org.pl/sposob-drew-lochera-wdrozenie-lean-srodowisku-uslugowym [dostęp 28.04.2016]. 